\title{
Türkiye de İthalat İhracat İle Enflasyon Arasında Nedensellik Analizi
}

\author{
Alper Gedik ${ }^{1 *}$ \\ ${ }^{1}$ Selçuk Üniversitesi, Beyşehir Ali Akkanat İşletme Fakültesi, İşletme Bölümü, Konya, Türkiye, ORCID: 0000-0002-9085-5605
}

(İlk Geliş Tarihi 8 Nisan 2020 ve Kabul Tarihi 26 Mayıs 2020)

(DOI: 10.31590/ejosat.734408)

ATIF/REFERENCE: Gedik, A. (2020). Türkiye de İthalat İhracat İle Enflasyon Arasinda Nedensellik Analizi. Avrupa Bilim ve Teknoloji Dergisi, (19), 323-333.

\begin{abstract}
Özet
Enflasyon ülkeler açısından çc̈zülmesi gereken ekonomik sorunların başında gelmektedir. Özellikle dışa açık ekonomilerde enflasyona neden olan içsel faktörlerin yanında dışsal birçok faktörde ön plana çıkmaktadır. Diğer ülkelerle olan ithalat ve ihracat ilişkileri ülkelerin enflasyonun oluşumuyla ne oranda bağlantılı olduğunu öğrenmek, ülkelerdeki ekonomi politikalarında karar alıcılar açısından önem arz etmektedir. Buradan yola çıkarak enflasyon ile ithalat ihracat verileri arasındaki nedensellik ilişkisinin uygun dönemler itibari ile incelenmesinin gerekli olduğu düşünülmektedir.

Çalışmada enflasyon ile ihracat ve ithalat verileri arsındaki ilişki analiz edilmiştir. Çalışmada Türkiye İstatistik Kurumunun açıkladığı verilerden yararlanılmıştır. Çalışma 2008 ile 2016 yıllarını kapsamaktadır. Çalışmada bu yıllara ait aylık veriler kullanılmıştır. Çalışmada seriler durağan hale getirildikten sonra Johansen eşbütünleşme testi ve Granger nedensellik analizi seriler üzerinde uygulanmıştır. Çalışmada eşbütünleşme analizi sonucunda seriler arsında anlamlı bir ilişki tespit edilmiştir. Yapılan Granger nedensellik analiz sonucunda İhracat-İthalat ve İthalat-İhracat sonucuna bakıldığında ihracat ithalatın nedeni değildir. İthalat ihracatın nedenidir. Sonuca bakıldığında tek taraflı bir nedensellik vardır. Enflasyon-İhracat ve İhracat-Enflasyon sonucunda enflasyon ihracatın nedenidir. İhracat enflasyonun nedenidir. Sonuç olarak iki değişsen arasında nedensellik vardır. Enflasyon-İthalat ve İthalatEnflasyon sonucunda enflasyon ithalatın nedeni değildir. İthalat enflasyonun nedenidir. Sonuca bakıldığında tek taraflı bir nedensellik vardir.
\end{abstract}

Anahtar Kelimeler: Enflasyon, İthalat, İhracat, Nedensellik Analizi.

\section{Causality Analysis Between Import Export and inflation in Turkey}

\begin{abstract}
Inflation is one of the economic problems that need to be solved for countries. Especially in outward-oriented economies, besides the internal factors that cause inflation, external factors come to the fore. Import and export relations with other countries are important for decision makers in the economic policies of the countries to learn how countries are related to the formation of inflation. From this point of view, it is thought that it is necessary to examine the causality relationship between inflation and import and export data as of appropriate periods.

In the study, the relationship between inflation and export and import data was analyzed. The study has utilized data provided by the Turkey Statistical Institute. The study covers the years 2008 and 2016. Monthly data for these years were used in the study. After the series became stationary in the study, Johansen cointegration test and Granger causality analysis were applied on the series. In the study, as a result of cointegration analysis, a significant relationship was determined between the series. As a result of the Granger causality analysis, export-import and import-export results are not the reason of import. Imports are the cause of exports. Looking at the result, there is a one-sided causality. Inflation-Export and Export-Inflation is the cause of exports as a result of inflation. Export is
\end{abstract}

${ }^{1}$ Sorumlu Yazar: Selçuk Üniversitesi, Beyşehir Ali Akkanat İşletme Fakültesi, İşletme Bölümü, Konya, Türkiye, ORCID: 0000-0002-9085-5605, alpergedik@selcuk.edu.tr 
the cause of inflation. As a result, there is causality between the two variables. Inflation-Import and Import-Inflation is not the cause of imports as a result of inflation. Imports are the cause of inflation. Looking at the result, there is a one-sided causality.

Keywords: Inflation, Import, Export, Causality Analysis.

\section{Giriș}

Dış ticaret ülkeler arası ilişkilerin geliştirilerek sürdürülebilmesinde önemli bir yere sahiptir. Ülkelerin iç piyasalarda üretilen mal ve hizmetlerin, dış piyasalara açılarak Pazar bulması ülke ekonomilerine sağlayacağı katkı açısından önemlidir. Ayrıca ülkede üretilsin veya üretilme imkânı olmayan her türlü mal ve hizmet dış piyasalardan ülkeye getirilerek pazarlanabilmesi de tüketiciler açısından avantajlar sağlamaktadır. Burada legal olan mallar için bu durum geçerlidir. Dış ticaret bu açıdan ülke ekonomilerin gelişmesi ve toplumsal ihtiyaçların karşılanabilmesi açısından ülkelere büyük avantajlar sağlamaktadır.

Ülkelerin ekonomik sorunlarının başında gelen bir kavram olan enflasyon; fiyatlar genel seviyesindeki artı̧ı ifade eder. Enflasyon yaşandığ 1 ülkenin para biriminin diğer ülke para birimleri karşısında değerinin düşmesini de beraberinde getirir. Enflasyon ile ülkelerin para birimlerinin alım güçlerinde düşme söz konusu olmaktadır. Ülkedeki yerleşikler yerli paralarının alım gücünün düşmesinden dolayı yabancı paralara yöneliş gösterebilirler. Bu durum enflasyonun armasını sağlamakla beraber dış ticaret ve kambiyo piyasasını da etkilemektedir. Enflasyonun dış ticarette ithalat ve ihracat üzerine farklı etkileri olabilmektedir. İthalat açısından enflasyon ithal edilen ürünlerin fiyatlarının artmasından dolayı ithalatı özendirici bir etki oluşturabilmektedir. İhracat açısından ise, ihraç mallarııın fiyatlarının artması dış piyasada mal ve hizmet rekabetini olumsuz etkileyerek ihracatın azalmasına sebebiyet verebilmektedir. $\mathrm{Bu}$ nedenlerden dolayı enflasyonun olduğu ülkelerin dış ticaret dengesinde bozulmaların olması kaçınılmazdır.

Özellikle enflasyonun Türkiye ekonomisinde çok fazla görülüyor olması, bu alanda yapılan çalışmalara ihtiyacı da arttırmaktadır. Ekonomi politikaları açısından enflasyon ile mücadele her zaman gündemdeki yerini korumaktadır. Çalışmada 2008 ile 2016 verileri aylık bazda kullanılarak dış ticaret ve enflasyon ilişkisi incelenmesi amaçlanmıştır. Türkiye ekonomisi açısından 2001 krizi sonrası değişen ekonomik yapı bir milat teşkil etmektedir. 2001 krizi sonrası sabit döviz kuru sistemi yerini serbest döviz kuruna bırakarak dış ticaret ve enflasyon açısından yeni bir iliş̧i döneminin başlangıcı olmuştur denilebilir. Sadece döviz kuru değil onunla beraber uygulamaya geçilen güçlü ekonomiye geçiş programı da ekonomik yapının değişiminde önemli bir etken olmuştur. 2002 sonrası toparlanmaya çalışan ve başarılı bir ivme dönemine giren ekonomi 2008 yılında yaşanan küresel ekonomik krize kadar bu durumunu sürdürmüştür. 2008 sonrası hem dünya hem Türkiye ekonomisi açısından bazı yeni adımların atıldığı yeni bir ekonomik süreçler dizisi ortaya çıkmıştır. Bu sebeple 2008- 2016 yılları arası aylık verilerin özel olarak değerlendirilmesinin literatür açısından daha fazla yarar sağlayacağı düşünülmektedir.

Çalışmada, ilk olarak dış ticaret ve enflasyon kavramları değerlendirilmiştir. Daha sonra literatür taraması yapılarak çalışmada kullanılan model ve yöntem açıklanmıştır. Ardından araştırma bulguları verilerek değerlendirmeler yapılmıştır. En son olarak ise sonuç ve genel değerlendirme kısmıyla çalışma tamamlanmıştır.

\section{Dış Ticaret Kavramı Ve Dış Ticareti Açıklayan Teoriler}

Genel bir tanımlama yapılması gerekirse dış ticaret ülkeler arası belli bir bedel üzerinden yapılan ticari işlemdir. Ülkeler açısından gelişmenin en önemli kaynaklarının başında dış ticaret gelmektedir. Ülkeler başka ülkelerde ihtiyaçları olan malları satın alırken kendi ihtiyaçlarından fazla olan mal ve hizmetlerinde ihraç etmek suretiyle ülkenin gelişmesini sağlamaktadırlar. Dış ticaret mal alımı ve satımı işlemleridir. Dış ticarette başka ülkeye mal satımı ihracat, mal alımı ise ithalat olarak ifade edilir (Kara, 2012: 34). Dış ticaret ülkelerin gelişmişlik düzeylerine göre farklılık gösterebildiği gibi coğrafi etkenler ve yeraltı kaynakları da dış ticaretin yönünü belirlemekte etkin olmaktadır. Günümüzde genellikle gelişmekte olan ülkeler ham madde ve yarı mamul ürünlerini gelişmiş ülkelere satmaktadır. Gelişmiş ülkeler ise mamullerini gelişmekte olan ülkelere satmaktadır. Azgelişmiş ülkeler ise sanayi tesisleri yetersizliği olan ülkeler olduğu için genellikle ihracat kalemleri hammadde olabilmektedir. İthalatta ise ekonomik yetersizlik nedeniyle zaruri mal ve hizmetlerin ithalatı ancak mümkün olabilmektedir. Bu zaruri mallar gıda ve yatırım malları olabilmektedir. Genel olarak dünya dış ticareti özellikle gelişmekte olan ülkeler ile gelişmiş ülkeler arsında dış ticaret önem kazanmaktadır (Karluk, 1991: 154).

\subsection{Klasik Dış Ticaret Teorileri}

Kuramlar açısından dış ticarete bakışta genellikle durağan koşullar dikkate alınmaktadır. Dış ticarette rasyonelliğin sağlanması ve üretim faktörlerinin etkin kullanılması dış ticaret kuramları açısından genel hareket noktaları olmaktadır. Dış ticaret yaklaşımlarına arz ve talep yönüyle bakacak olursak genellikle klasik iktisatçılar dış ticareti arz yönüyle değerlendirirken ne klasik iktisatçılar dış ticaretin talep yönünü ön plana çıkarmışlardır. Her iki anlayışta da temel etken dış ticaretin önemi vurgulanması açısından önem arz etmektedir (Yörük, 2008: 78). Adam Smith'in geliştirdiği klasik dış ticaret teorilerinden biri mutlak üstünlükler teorisidir. Bu teoride iki ülke ve iki mal söz konusudur. Malı daha ucuza hangi ülke üretiyorsa onda uzmanlaşmalı diğer malı diğer ülke üretmelidir. Yani ülkeler daha az maliyetle ürettikleri üründe uzmanlaşarak onu fazlasını diğer ülkeye satmalıdır. Diğer maliyeti daha yüksek olan malı ise üretmeyip daha düşük maliyetle üreten ülkeden ihraç etmelidirler. Bu teori emek faktörünün temel alındığı diğer etmenlerin maliyete dâhil edilmediği bir teoridir (Bayraktutan, 2003: 177). Adam Smith'ten sonra David Ricardo sahneye çıkarak karşılaştırmalı üstünlükler teorini geliştirmiştir. Ricardo bu teoride eğer her ülke iki malda da üstün se faktöründen yola çıkmaktadır. Böyle bir durumda ülkeler maliyeti düşük ürün yerine maliyet oranı düşüklük durumunu ortaya koymaktadır. Karşılaştırmalı üstünlükler 
teorisinde maliyetin düşük olması değil ülkeler arsı maliyet farklılığının olması esas teşkil etmektedir (Şentürk,2007: 42-43). Bu teoriler beraberinde firsat maliyeti kavramını da getirmektedir. Çünkü bir ürünü daha fazla üretmek için diğer ürünü üretmekten vazgeçme durumu ortaya çıkmaktadır. Bu vazgeçilen değer firsat maliyeti olarak ifade edilmektedir. Fırsat maliyeti açıklanırken ülkelerin üretim imkânları eğrileri kullanılabilmektedir (İyibozkurt, 1995: 30-31). Bunların dişında klasik dış ticaret teorilerinden bir tanesi de faktör donatım teorisidir. Bu teoride ülkelerin elinde buluna üretim faktörleri üzerin den bir açıklama yapılmaktadır. Ülkeler hangi üretim faktöründe daha fazla yeterliliğe sahipse o alanda mal ve hizmet üretmeli, üretim faktörlerinin yetersiz olduğu mal ve hizmeti satın almadır görüşünü ifade eder (Şentürk, 2007: 46). Bu teori ayrıca bolluk varsayımını dikkate almaktadır. Ülkede bol olan unsurun ucuz olacağı ve böylelikle o mal ve hizmetin üretim maliyetlerinin düşük olacağı varsayımıyla hareket edilmektedir (Ateş, 2005: 25-26).

\subsection{Dış Ticareti Açıklayan Alternatif Teoriler}

Teoriler açısından dış ticareti açıklayan alternatif teorilerde söz konusudur. Bu teorilere göre dış ticaret yapmanın klasik teorilerin üzerinde durmadığı durumları dikkate alınmaktadır. Özellikle coğrafi farklılıklar ve ticaretin belli bölgelerde yoğunlaşması gibi temel hususlar değerlendirilmektedir. Ticarete konu olan malın taşıma ve lojistik maliyetleri ile Pazar payları da dikkate alınmaktadır. Ayrıca ülkelerin uyguladıkları dış ticaret politikaları ve buna göre şekillenen dış ticaret rejimleri büyük ölçüde alternatif teorilerin temelini oluşturmaktadır (Özel, 2012: 9). Alternatif dış ticaret teorilerinden ilki 1956 yılında Irving Kravis'in ortaya koyduğu varlık teorisidir. Bu teorinin temelinde ülkelerde üretimi olmayan mal ve hizmetler vardır. Ülkeler kendinde olmayan mal ve hizmeti mecburen dışardan ithal etmek zorundadır varsayımına dayanmaktadır (Ordu, 2013: 38). Bir başka teori ise Posner tarafından 1961 yılında ortaya atılan teknoloji açı̆̆ı teorisidir. Bu teoride bazı varsayımlar söz konusudur. Bunlar gümrük tarifelerinin olmaması döviz kuru değerinin değişmemesi, istihdamın tam olması, ve zevk tercih olarak tüketicilerin standart olması gibi unsurlardır. Teoriye göre endüstrilerde en önemli bir hususun teknoloji seviyesi olmasıdır. Her ülke teknoloji olarak aynı seviyede olamayacağı için teknolojisi yeterli ülkelerde endüstrilerin daha düşük maliyetle daha fala mal ve hizmet üretmesi mümkün olabilmektedir. Bu teknolojik farklılıklar ülkeler arası endüstrilerde üretim farklılıklarına neden olmaktadır. Farklı iki ülkede aynı üretim malını üreten iki firmanın yöntem ve üretim açısından farklılıkları söz konusu olabilmektedir (Türker, 2002: 33-34). Yine teknolojik açık teorisini referans alan yeni mal geliştirme teorisini ise Raymond Vernon 1966 yılında ortaya atmıştır. Bu teoride malın ilk ortaya çıkışı ile seri üretim aşamaları arasında çeşitli aşama dönemleri olmaktadır. Teoride bir mal ilk olarak icat eden firma tarafından ortaya çıkarılarak pazara sunulur ve öteki ülkelere ihracatı yapılabilir. Böyle durumda mal hakkında teknolojisi ve üretimiyle ilgili bilgiler icat yapan firma tarafından bilinmektedir. Zamanla malın piyasalara yayılması diğer firmaların malı ve üretim yöntemlerini tanımasını sağlayacaktır. Böylelikle mal başka ülkelerde ki firmalar tarafından da üretilmeye başlanarak standart mallar arsına girecektir. Gelişmekte olan ülkeler üretim teknolojilerindeki yetersizlikten ötürü üretimi standartlaşmış olan malları ithal etmektedirler gelişmiş ülkeler ise yeni üretilmiş teknolojisi yeni olan malları ihraç etme eğilimindedirler (Kebapçı, 2011: 62-63). Bu teorilerin dışında Keesing ve Kravis tarafindan geliştirilen nitelikli işgücü açısından kendini geliştirebilmiş ülkelerin nitelikli mal ve hizmet üretmede uzmanlaşacağı görüşünü savunan nitelikli işgücü teorisi vardır (Oktay, 2005: 51). Linder tarafindan 1961 yılında atılan benzer gelir seviyesine sahip ülkelerin benzer ürünlerin ticaretinin yoğun olacağı varsayımına dayanan tercihlerde benzerlik teorisidir (Atik, 2006: 34-35). Son olarak diş ticareti açıklayan alternatif teorilerden biri de ölçek ekonomileri teorisidir. Bu teori maliyet fonksiyonunun pozitiflik v homojenlik varsayımına dayandığı görüşünü ifade etmektedir (Özarslan, 1998: 104).

Gümrük mevzuatı ve dış ticaret mevzuatı çerçevesince bir malın Türkiye gümrük bölgesi sınırları dışına çıkarılmasına ihracat, Türkiye gümrük bölgesi sınırlarına sokulmasına ise ithalat denilmektedir (Kaya ve Turguttopbaş, 2012: 3-8).Aşağıda çalışmamıza konu olan Türkiye'nin ihracat ve ithalat verileri Türkiye İstatistik Kurumu verilerinden alınarak kullanılmıştır. Türkiye'nin ihracat ve ithalatı toplam dış ticaret hamini vermektedir. Ayrıca dış ticaret açığı olarak ifade edilen ihracat ile ithalat arasındaki negatif farkı ifade etmektedir. İhracat ile ithalat arsındaki fark pozitif ise bu durum dış ticaret fazlası olarak ifade edilmektedir. 
European Journal of Science and Technology

Tablo 1: Türkiye'nin 2008 ve 2016 ylllarındaki aylık ihracat oranlarl.

\begin{tabular}{|c|c|c|c|c|c|c|c|c|c|}
\hline Yll/Ay & $\%$ & Yıl/Ay & $\%$ & Yıl/Ay & $\%$ & Yıl/Ay & $\%$ & Yıl/Ay & $\%$ \\
\hline 2008 & & 2009 & & 2010 & & 2011 & & 2012 & \\
\hline 01 & 62,0 & 01 & $-25,8$ & 01 & $-0,7$ & 01 & 22,0 & 01 & 8,3 \\
\hline 02 & 44,7 & 02 & $-23,9$ & 02 & $-2,0$ & 02 & 21,7 & 02 & 16,8 \\
\hline 03 & 27,6 & 03 & $-28,6$ & 03 & 21,2 & 03 & 19,5 & 03 & 11,8 \\
\hline 04 & 36,7 & 04 & $-33,5$ & 04 & 24,3 & 04 & 26,4 & 04 & 6,4 \\
\hline 05 & 36,4 & 05 & $-41,1$ & 05 & 33,4 & 05 & 11,7 & 05 & 20,0 \\
\hline 06 & 31,1 & 06 & $-29,2$ & 06 & 14,6 & 06 & 18,9 & 06 & 16,6 \\
\hline 07 & 40,9 & 07 & $-28,1$ & 07 & 5,6 & 07 & 24,0 & 07 & 8,2 \\
\hline 08 & 26,4 & 08 & $-29,0$ & 08 & 8,7 & 08 & 31,9 & 08 & 14,1 \\
\hline 09 & 41,5 & 09 & $-33,7$ & 09 & 5,1 & 09 & 20,7 & 09 & 20,5 \\
\hline 10 & $-1,7$ & 10 & 3,8 & 10 & 8,6 & 10 & 8,6 & 10 & 10,8 \\
\hline 11 & $-17,0$ & 11 & $-5,2$ & 11 & 5,4 & 11 & 18,1 & 11 & 24,1 \\
\hline 12 & $-20,6$ & 12 & 30,2 & 12 & 17,6 & 12 & 5,5 & 12 & 1,0 \\
\hline Yll/Ay & $\%$ & Yıl/Ay & $\%$ & Yıl/Ay & $\%$ & Yıl/Ay & $\%$ & & \\
\hline 2013 & & 2014 & & 2015 & & 2016 & & & \\
\hline 01 & 11,0 & 01 & 8,0 & 01 & $-0,8$ & 01 & $-22,4$ & & \\
\hline 02 & 5,4 & 02 & 5,4 & 02 & $-6,3$ & 02 & 1,1 & & \\
\hline 03 & $-0,7$ & 03 & 11,9 & 03 & $-14,7$ & 03 & 1,9 & & \\
\hline 04 & $-1,3$ & 04 & 7,2 & 04 & $-0,2$ & 04 & $-10,5$ & & \\
\hline 05 & 1,1 & 05 & 3,0 & 05 & $-19,0$ & 05 & 9,2 & & \\
\hline 06 & $-6,3$ & 06 & 3,9 & 06 & $-7,2$ & 06 & 7,7 & & \\
\hline 07 & 1,8 & 07 & 2,2 & 07 & $-16,6$ & 07 & $-11,5$ & & \\
\hline 08 & $-13,4$ & 08 & 2,4 & 08 & $-3,2$ & 08 & 7,3 & & \\
\hline 09 & 0,8 & 09 & 4,0 & 09 & $-14,7$ & 09 & $-5,9$ & & \\
\hline 10 & $-8,6$ & 10 & 7,0 & 10 & 2,7 & 10 & $-3,4$ & & \\
\hline 11 & 3,3 & 11 & $-8,0$ & 11 & $-10,6$ & 11 & 9,5 & & \\
\hline 12 & 4,5 & 12 & 0,7 & 12 & $-11,4$ & 12 & 8,8 & & \\
\hline
\end{tabular}

Kaynak: tuik.gov.tr 
Tablo 2: Türkiye’nin 2008 ve 2016 yıllarındaki ithalat değişim oranlart.

\begin{tabular}{|c|c|c|c|c|c|c|c|c|c|}
\hline Yıl/Ay & $\%$ & Yıl/Ay & $\%$ & Yıl//Ay & $\%$ & Y.ll/Ay & $\%$ & Yll/Ay & $\%$ \\
\hline 2008 & & 2009 & & 2010 & & 2011 & & 2012 & \\
\hline 01 & 54,3 & 01 & $-43,2$ & 01 & 26,0 & 01 & 44,6 & 01 & 3,3 \\
\hline 02 & 40,8 & 02 & $-43,4$ & 02 & 29,8 & 02 & 48,7 & 02 & 1,5 \\
\hline 03 & 27,0 & 03 & $-37,4$ & 03 & 42,8 & 03 & 44,1 & 03 & $-4,5$ \\
\hline 04 & 38,5 & 04 & $-43,4$ & 04 & 47,7 & 04 & 40,2 & 04 & $-8,0$ \\
\hline 05 & 29,3 & 05 & $-43,7$ & 05 & 35,5 & 05 & 43,3 & 05 & 3,0 \\
\hline 06 & 36,5 & 06 & $-35,8$ & 06 & 21,9 & 06 & 41,8 & 06 & $-5,4$ \\
\hline 07 & 35,1 & 07 & $-37,5$ & 07 & 25,1 & 07 & 31,0 & 07 & $-1,1$ \\
\hline 08 & 31,1 & 08 & $-33,5$ & 08 & 20,5 & 08 & 27,5 & 08 & $-4,3$ \\
\hline 09 & 23,7 & 09 & $-30,2$ & 09 & 25,3 & 09 & 35,5 & 09 & $-6,0$ \\
\hline 10 & $-4,4$ & 10 & $-14,5$ & 10 & 35,4 & 10 & 15,2 & 10 & $-5,7$ \\
\hline 11 & $-27,4$ & 11 & 4,5 & 11 & 35,8 & 11 & 8,8 & 11 & 12,3 \\
\hline 12 & $-29,2$ & 12 & 31,7 & 12 & 36,9 & 12 & 0,2 & 12 & $-3,7$ \\
\hline $\mathbf{Y} \mathbf{l} / \mathbf{A y}$ & $\%$ & Yıl/Ay & $\%$ & Yıl/Ay & $\%$ & Yıl/Ay & $\%$ & & \\
\hline 2013 & & 2014 & & 2015 & & 2016 & & & \\
\hline 01 & 7,6 & 01 & 2,6 & 01 & $-13,7$ & 01 & $-19,2$ & & \\
\hline 02 & 9,0 & 02 & $-6,0$ & 02 & $-7,1$ & 02 & $-8,0$ & & \\
\hline 03 & $-0,6$ & 03 & $-3,1$ & 03 & $-6,0$ & 03 & $-5,1$ & & \\
\hline 04 & 18,4 & 04 & $-9,5$ & 04 & $-11,1$ & 04 & $-11,9$ & & \\
\hline 05 & 6,9 & 05 & $-10,2$ & 05 & $-14,4$ & 05 & $-3,8$ & & \\
\hline 06 & 2,8 & 06 & $-1,0$ & 06 & $-12,5$ & 06 & 7,0 & & \\
\hline 07 & 10,2 & 07 & $-13,2$ & 07 & $-8,6$ & 07 & $-19,4$ & & \\
\hline 08 & $-3,3$ & 08 & 7,1 & 08 & $-18,1$ & 08 & 4,0 & & \\
\hline 09 & 3,5 & 09 & $-0,1$ & 09 & $-25,2$ & 09 & $-0,7$ & & \\
\hline 10 & 3,7 & 10 & $-1,5$ & 10 & $-11,8$ & 10 & 0,5 & & \\
\hline 11 & 2,2 & 11 & $-0,1$ & 11 & $-25,3$ & 11 & 6,0 & & \\
\hline 12 & 16,7 & 12 & $-5,8$ & 12 & $-17,4$ & 12 & 2,3 & & \\
\hline
\end{tabular}

Kaynak: tuik.gov.tr

\section{Enflasyon Kavramı, Türleri ve Enflasyonla İlgili Yaklaşımlar}

Enflasyon ekonomideki olumsuz durumlardan biri olarak görülmektedir. Tanım olarak fiyatlar genel seviyesinde sürekli artı olarak ifade edilebilmektedir. Enflasyon kelime manasıyla Latince kökenli olup şişkinlik anlamına gelmektedir. Fiyatlar genel seviyesindeki şişmeyi açılaması bakımından enflasyon süreçleri ifade eden bir kavramdır. Ekonomide enflasyon durumu olumsuz bir süreci ifade etmektedir. Enflasyonu ortaya çıkmasına neden olan etkenler önem arz etmektedir. Ekonomide yaşanan enflasyon sorunu başka sorunlara da neden olabilmektedir. Ülkeler açısından enflasyon sorunu söz koşuysa ekonomi politikalarında enflasyonla mücadele ön plana çıkmaktadır. Enflasyon sorunun çözülmesi diğer ekonomik problemlerin çözümü açısından öncelik teşkil etmektedir (Karaçor, 2007: 100). Türkiye açısından günümüzde ekonomik, jeopolitik bir çok olay enflasyon artışına neden olabilmekledir (Ak, 2019:500).

\subsection{Enflasyon Türleri}

Enflasyon ekonomide oluşumuna neden olan birçok faktör söz konusudur. Enflasyonu türlerine ayırmada bu nedenlerden hareket edilmektedir. Eğer enflasyon talep kaynaklıysa talep enflasyonu olarak, eğer maliyet kaynaklı ise maliyet enflasyonu, yapısal 
sorunlardan kaynaklı ise yapısal enflasyon ve ithalatın getirdiği yükten kaynaklanıyorsa ithalat enflasyonu olarak türlere ayrılabilmektedir (Saraç, 2009:5). Talep enflasyonu talepte meydana gelen artışlardan kaynaklanan türdür. Ĕger talep ani artışlarla arzdan fazla duruma gelirse böyle bir durum arz eksikliğini ve fiyatların hızlı artışını beraberinde getirecektir. Talebin arması kamu ve özel harcamaların artması anlamını taşımaktadır. Devletin kamu hizmetleri yapmak adına bazı durumlarda talebini arttırması enflasyona neden olabilmektedir. Ayrıca özel sektörün kredi imkânlarının artması kredi oranlarının düşmesi de harcamaları arttırarak enflasyona neden olabilmektedir (Altınok, 2004: 307). Maliyet enflasyonunda ise girdi faktörlerinin biri veya birkaçında fiyat artışı olması durumu sonucu üretilen mal ve hizmetin fiyatının arması sonucu oluşan enflasyon durumu ifade edilir. Maliyet enflasyonu vergi artışından döviz kurlarının yükselmesi sonucu ithalat girdililerinin fiyatının yükselmesine adar pek çok sebeple oluşabilmektedir. Ayrıca olağan üstü durum ve olaylarda maliyet enflasyonun oluşumunda etkilidir (Ulusoy, 2006: 195).yapısal enflasyon durumu ise Vazguez tarafindan ortaya atılan yapısalcı teoriye dayanmaktadır. Bu teoriye göre enflasyon parasal nedenlerden değil ekonomik yapıdaki sorunlardan kaynaklanmaktadır. Ekonomide meydana gelen her türlü arızi durum enflasyona neden olabilmektedir (Dinçer, 1994: 43). Son olarak ithalatın artması veya ithal girdilerin fiyatlarındaki artış enflasyona neden olabilmektedir. Bu durumda ithalat enflasyonu söz konusu olabilmektedir (Durukan, 1988: 13).

\subsection{Enflasyon ile İlgili Yaklaşımlar}

Tarihsel süreç içerisinde enflasyonu açıklamaya yönelik birçok yaklaşım geliştirilmiştir. Bunlar klasik ekolün görüşlerinden oluşan klasik yaklaşımlar, Keynes'in görüşlerinden oluşan Keynesyen yaklaşımlar, para teorisine yönelik görüş çerçevesinden oluşan parasalcı yaklaşımlar ve ekonomik yapıyı açıklayan görüşlerden oluşan yapısalcı yaklaşımlardır (Saraç, 2009: 13). Klasik yaklaşımda ekonomik denge görünmez el teorisinden hareketle kendi kendine oluşmaktadır. Fiyatların olumunda denge ise para miktarına bağlı olarak oluşmaktadır. Para arzı ve para talebi dengenin değişmesine imkân oluştururken enflasyona da neden teşkil etmektedir. Klasik teoride para arzının arttırılması piyasa müdahalesi ile olabilecek bir durumu ifade eder. Enflasyon nedeni olarak para politikası uygulayıcıların müdahalelerinin enflasyona sebep olacağını ifade ederler (Hiç, 1994b: 399). Bir başka yaklaşım olan Keynesyen görüşe göre ise, devletin piyasaya müdahale etmesi ve piyasada oluşan fiyatın esnek olamaması enflasyonun nedeni olarak ifade edilir. Ayrıca esnek olmayan fiyat yapısı rekabet olgusunu engellemektedir görüşü savunulur (Erim, 2007: 193). Parasalcı yaklaşım da ise ekonomideki karar birimlerinin uyguladığı yanlış para politikası enflasyona sebep olmaktadır. Monetarist yaklaşım olarak da ifade edilen parasalcı görüş doğru para politikası uygulamaları ile ekonomik istikrarın tekrar sağlanacağını savunmaktadırlar (Parasız, 1996: 9, 10; Ataç, 2006: 13).son olarak yapısalcı yaklaşımda ise, enflasyonun ekonomik yapıdaki bozukluklardan kaynaklandığı vurgulanmaktadır. Yapısal aksaklıklar giderilmeden uzun vadede bir fiyat istikrarının sağlanamayacağını ifade ederler (Alkan, 2004: 28).

Sonuç itibari ile enflasyon üzerine farklı görüşlerin mevcudiyeti söz konusudur. Bu farklı görüşler enflasyon üzerine çalışmaların sayısının ve öneminin göstergeleri olmaktadır. Enflasyon düşürülmesi ülkeler açısından ve çalışma yapanlar açısından değerlenmektedir. Enflasyonla mücadelede uygulanacak politikaların doğru olması ülkeler açısından büyük önem arz eder. Enflasyonu engellemek veya enflasyonu düşürmek maksadı ile birçok ekonomik araç ekonomi politikalarında kullanılabilmektedir. Özellikle para ve aliye politikası araçlarının birlikte kullanılması durumu daha etkin olabilmektedir. Enflasyonu önlemek ek mali yükümlülükleri de beraberinde getirebilmektedir. Ülkeler enflasyonla mücadelede bu mali yükümlülüklere katlanmak zorunda kalmaktadırlar (Saraç, 2009: 17). Bu maliyetlerden bazılarını ifade edecek olursak; enflasyon geleceğe ilişkin tahminleri belirsizleştirmektedir. Yapılan yatırımlar azalarak ekonomik büyüme olumsuz etkilenmektedir. Parasal istikrarı bozarak diş ticarette bir daralmaya sebep olabilmektedir. Enflasyon tasarrufların yönünde olumsuz etkilemektedir. Tasarrufların yatırıma döşüm oranı azalarak yatırım azaltıcı etki oluşturmaktadır (Berber ve Artan, 2004: 3). Sonuç olarak enflasyon ülkeye olumsuz ekonomik sonuçlar getirerek büyümeyi negatif olarak etkilemektedir. Enflasyona sebep olan unsurların doğu tespit edilmesi ülkeler açısından önem arz eder. Ülkeler ekonomi politikasında bu sebeplere yönelik yol haritaları benimseyerek enflasyonla mücadelede doğru adımlar atabilmektedir (Y1lmaz vd., 2002: 38). 
Tablo 3: Türkiye'nin 2008 ve 2016 yıllarındaki aylı enflasyon verileri.

\begin{tabular}{|c|c|c|c|c|c|c|c|c|c|}
\hline Yll/Ay & $\%$ & Yll/Ay & $\%$ & Yıl/Ay & $\%$ & Yıl/Ay & $\%$ & Yıl/Ay & $\%$ \\
\hline 2008 & & 2009 & & 2010 & & 2011 & & 2012 & \\
\hline $2008-1$ & 8,17 & $2009-1$ & 9,5 & $2010-1$ & 8,19 & 2011-1 & 4,9 & $2012-1$ & 10,61 \\
\hline $2008-2$ & 9,1 & $2009-2$ & 7,73 & $2010-2$ & 10,13 & $2011-2$ & 4,16 & $2012-2$ & 10,43 \\
\hline $2008-3$ & 9,15 & $2009-3$ & 7,89 & $2010-3$ & 9,56 & $2011-3$ & 3,99 & $2012-3$ & 10,43 \\
\hline $2008-4$ & 9,66 & $2009-4$ & 6,13 & $2010-4$ & 10,19 & $2011-4$ & 4,26 & $2012-4$ & 11,14 \\
\hline $2008-5$ & 10,74 & $2009-5$ & 5,24 & $2010-5$ & 9,1 & $2011-5$ & 7,17 & $2012-5$ & 8,28 \\
\hline $2008-6$ & 10,61 & $2009-6$ & 5,73 & $2010-6$ & 8,37 & $2011-6$ & 6,24 & $2012-6$ & 8,87 \\
\hline $2008-7$ & 12,06 & $2009-7$ & 5,39 & $2010-7$ & 7,58 & $2011-7$ & 6,31 & $2012-7$ & 9,07 \\
\hline $2008-8$ & 11,77 & $2009-8$ & 5,33 & $2010-8$ & 8,33 & $2011-8$ & 6,65 & $2012-8$ & 8,88 \\
\hline 2008-9 & 11,13 & $2009-9$ & 5,27 & $2010-9$ & 9,24 & $2011-9$ & 6,15 & $2012-9$ & 9,19 \\
\hline $2008-10$ & 11,99 & $2009-10$ & 5,08 & $2010-10$ & 8,62 & $2011-10$ & 7,66 & $2012-10$ & 7,8 \\
\hline $2008-11$ & 10,76 & $2009-11$ & 5,53 & 2010-11 & 7,29 & 2011-11 & 9,48 & 2012-11 & 6,37 \\
\hline 2008-12 & 10,06 & $2009-12$ & 6,53 & $2010-12$ & 6,4 & 2011-12 & 10,45 & 2012-12 & 6,16 \\
\hline Yll/Ay & $\%$ & Yll/Ay & $\%$ & Yll/Ay & $\%$ & Yll/Ay & $\%$ & & \\
\hline 2013 & & 2014 & & 2015 & & 2016 & & & \\
\hline 2013-1 & 7,31 & 2014-1 & 7,75 & $2015-1$ & 7,24 & 2016-1 & 9,58 & & \\
\hline $2013-2$ & 7,03 & 2014-2 & 7,89 & $2015-2$ & 7,55 & 2016-2 & 8,78 & & \\
\hline $2013-3$ & 7,29 & 2014-3 & 8,39 & $2015-3$ & 7,61 & 2016-3 & 7,46 & & \\
\hline $2013-4$ & 6,13 & $2014-4$ & 9,38 & $2015-4$ & 7,91 & $2016-4$ & 6,57 & & \\
\hline $2013-5$ & 6,51 & $2014-5$ & 9,66 & $2015-5$ & 8,09 & $2016-5$ & 6,58 & & \\
\hline $2013-6$ & 8,3 & 2014-6 & 9,16 & 2015-6 & 7,2 & 2016-6 & 7,64 & & \\
\hline $2013-7$ & 8,88 & $2014-7$ & 9,32 & $2015-7$ & 6,81 & $2016-7$ & 8,79 & & \\
\hline $2013-8$ & 8,17 & $2014-8$ & 9,54 & $2015-8$ & 7,14 & 2016-8 & 8,05 & & \\
\hline 2013-9 & 7,88 & $2014-9$ & 8,86 & $2015-9$ & 7,95 & $2016-9$ & 7,28 & & \\
\hline 2013-10 & 7,71 & 2014-10 & 8,96 & 2015-10 & 7,58 & 2016-10 & 7,16 & & \\
\hline 2013-11 & 7,32 & 2014-11 & 9,15 & 2015-11 & 8,1 & 2016-11 & 7 & & \\
\hline 2013-12 & 7,4 & 2014-12 & 8,17 & $2015-12$ & 8,81 & 2016-12 & 8,53 & & \\
\hline
\end{tabular}

Kaynak: tuik.gov.tr

\section{Literatür Taraması}

Literatür incelendiğinde yer ve yabancı çok sayıda dış ticaret ve enflasyon paralelinde ve benzeri analizler gerçekleştirilen çalışmalar mevcuttur. Bu çalışmalar gerek uygulan yöntem gerekse uygulandığı dönem ve kullanılan veriler yönünden farklılaşmaktadır. Bu çalışmalardan bazıları aşağıda belirtilmiş̧ir.

Aktaş (2009) yaptığı çalışmasında 1996 ile 2007 yıllarını kapsayan dış ticaret ve büyüme arasındaki ilişsiyi incelemiştir. Çalışmada Granger nedensellik testi uygulanmıştır. Çalışma sonucunda kısa dönemde çift yönü, uzun dönemde ise tek yönlü nedensellik ilişkisi tespit etmişlerdir.

Baldemir ve Gökalp (1999), yılında yaptıkları çalışmalarında 1980 ile 1997 yılları arasında döviz kuru ile dış ticaret ilişkisini incelemişlerdir. Çalışmada Granger nedensellik analizi kullanmışlardır. Çalışmanın sonucunda döviz kurunun dış ticaret hadlerini etkilediğini tespit etmişlerdir.

Bayraktutan ve Arslan (2003), yılında yaptıkları çalışmalarında 1980 ile 2000 yılları arasını ithalat ile enflasyon verilerini kullanarak Granger nedensellik analizi ile değerlendirmişlerdir. Yapılan çalışmaya göre enflasyonun yükselmesi ithalatı olumsuz etkilemektedir sonucuna ulaşmışlardır.

Çeştepe, Yıldırım ve Bayar (2013) yaptıkları araştırmalarında 1974-2011 yıllarına ait Doğrudan Yabancı Yatırım, Ekonomik Büyüme ve Dış Ticaret: verilerini kullanarak TodaYamamoto yöntemiyle incelemişlerdir. Çalışma sonucunda gayri safi yurtiçi hâsıla ile ihracat arasında bir nedensellik ilişkisi olduğunu ifade etmişlerdir.

Gül ve Ekinci (2006) yılında yapılan çalışmada döviz kuru ile dış ticaret verileri arasındaki ilişki analiz edilmiştir. Çalışmada Granger nedensellik testi kullanılmıştır. Çalışma sonucunda dış ticaret ile döviz kuru arasında nedensellik ilişkisinin varlığı tespit edilmiştir.

Kaya ve yılmaz (2006) yılında yapmış oldukları çalışmalarında enflasyon ve ekonomik büyüme arasındaki ilişkiyi incelemişlerdir. 1983 ile 2001 dönemini Türkiye'nin 7 bölgesi üzerinde eşbütünleşme ve nedensellik testleri ile yapmışlardır. Sonuç olarak Marmara dışındaki bölgelerde enflasyonun ekonomik büyümeyi etkilediğini ifade etmişlerdir (Saraç, 2009: 73). 
Koch ve Rosensweigh (1992),yılında yaptıkları çalışmalarında dolardaki dalgalanmanın dış ticaret hadlerine etkisini ABD üzerinde incelemişlerdir. Çalışmada Granger nedensellik analizi yöntemini uygulamışlardır. Çalışma sonucunda dolardaki dalgalanmanın dış ticaret hadlerini az miktarda etkilediğini tespit etmişlerdir.

Koldhy-Sohrabian (1990), yılında yaptıkları çalışmalarında Japonya Kanada ve Almanya üzerinde dış ticaret ve enflasyon arsındaki ilişkiyi incelemişlerdir. Çalışmada Granger nedensellik analizi yönteminden yararlanmışlardır. Çalışma sonucunda Japonya ve Almanya için nedensellik tespit edilirken, Kanada için tespit edilmemiştir.

Mihaljek ve Klau (2001), yılında yaptıkları çalışmalarında 13 ülkenin 1995 ile 2000 yılları arasındaki döviz kuru ile enflasyon arsındaki ilişkiyi incelemişlerdir. Çalışmada granger nedensellik analizi yönteminden faydalanmışlardır. Çalışmadaki ülkelerden biri de Türkiye'dir. Çalışma sonucunda iki ülkede ithalat ile enflasyon arasında nedensellik ilişkisinin yüksek olduğu, dört ülkede aynı düzeyde birebir iliş̧i olduğu ve son yedi ülkede ise ilişkinin az olduğu tespit etmişlerdir.

Paul, Kearney ve Chowdhury (1997), yılında yaptıkları çalışmalarında 1960 ile 1989 yılları arasında enflasyon ile büyüme arsındaki ilişkiyi incelemişlerdir. Çalışmada yetmiş ülkeye ait veriler değerlendirilmiştir. Çalışmada granger nedensellik analizi yönteminden yararlanmışlardır. Çalışma sonucunda sadece 26 ülkede enflasyon ile büyüme arsınad ilişki tespit edilmişken, 16 ülkede birebir ilişki tespit edilmiş, geri kalan 28 ülkenin ise herhangi bir nedensellik ilişkisinden bahsedilemeyeceğini tespit etmişlerdir.

Ulke ve Ergün (2011), 1995 ile 2010 dönemini inceledikleri çalışmalarında enflasyon ve ithalat verilerini değerlendirmişlerdir. Çalışmada granger analizini uygulamışlardır. Yapılan çalışma sonucunda ithalat verileri ile enflasyon arasında kısa ve uzun dönemli eş bütünleşme olduğunu ve ithalatın enflasyonun nedeni olduğunu ifade etmişlerdir.

Yapraklı (2007), yılında yaptıkları çalışmalarında 1987 ile 2007 yılları arasında enflasyon büyüme arsındaki ilişkiyi incelemişlerdir. Çalışmalarında granger nedensellik analizi yöntemini kullanmışlardır. Çalışma sonucunda enflasyon ile büyüme arsında tek yönlü bir ilişkinin olduğunu tespit etmişlerdir.

\section{Araştırma Bulguları ve Değerlendirilmesi}

Granger Nedensellik analizi literatürde çok sıklıkla kullanılan bir analizdir. Bu analizde bağımlı ve bağımsız değişkenler kullanılmaktadır. Değişkenler arası ilişiklerin yönleri Granger analizi sayesinde tespit edilebilmektedir (Doğan vd. 2015: 111). Nedensellik ilişkileri ile ilk çalışma Granger (1969) tarafından yapılmıştır. Daha sonara Toda ve Yamamoto (1995), seriler arasında nedensellik ile ilgili çalışama yapmıştır. Ayrıca Hatemi-J (2012) Bootstrap nedensellik testleri ile zaman içerisindeki değişimleri incelemiştir. Grangerin analizi ilk ve en temel analiz olma özelliğini taşımaktadır. Granger analizi durağan seriler üzerine yapılan analizlerde daha etkin olabilmekteyken, gecikme uzunluğuna olan duyarlılığından dolayı eleştirilebilmektedir. Bu testte boş hipotez kullanılan serilerin birbiriyle ilişkisi olmadı yönündeki hipotezdir (Göçer ve Gerede, 2016: 37).

Yaptığımız literatür çalışmasından da yola çıkarak Türkiye için 2008 ve 2016 yılları arasındaki aylık enflasyon değerlerinin dış ticaret üzerindeki bağımlılı̆̆ını ölçeceğiz. Bu bağlamda kullanacağımız analiz tekniği, Granger nedensellik analizi olacaktır. Öncelikle Granger analizine geçmeden önce çalışmada verilerin birim kök analizi yapılarak durağan olup olmadıkları değerlendirilmiştir. Daha sonra durağan olan seriler üzerine eş bütünleşme analizi uygulanmıştır. Modelde uygulan değişkenlerin Johansen eşbütünleşme testi neticesinde serilerin eş bütünleşik olduğu tespit edilmiştir. Son olarak ise modelde ve seriler üzerine Granger nedensellik uygulaması yapılmış ve seriler arasındaki ilişkiler değerlendirilmiştir.

Tablo 4.Birim Kök Testi Sonuçlart

\begin{tabular}{|l|l|l|l|}
\hline Değişkenler & t-Statistic & Anlamlılık (p) I(0) & Gecikme Uzunluğu \\
\hline İhracat & -3.271488 & 0.0187 & 1 \\
\hline İthalat & -3.199867 & 0.0228 & 3 \\
\hline Enflasyon & -3.465758 & 0.0108 & 1 \\
\hline
\end{tabular}

İhracat, ithalat ve enflasyon değişkenleri için yapılan birim kök testi sonucuna bakıldığında ihracat değişkeni için 1. Gecikme uzunluğunda t-Statistic değerinin -3.27 ve anlamlılık değerinin de 0.0187 olduğu görülmektedir. İthalat değişkeni için 3 . Gecikme uzunluğunda t-Statistic değerinin -3.19 ve 0.0228 anlamlılık düzeyinde olduğu görülmektedir. Enflasyon değişkeninde ise 1. Gecikme uzunluğunda t-Statistic değeri -3.46 ve anlamlılık değeri 0.0108 olarak görülmektedir. Buradan yola çıkarak modelin sabitli ve trendli bir model olduğunu görülmektedir. Gözlem sayısı 106 olan tabloya bakıldığında alfa 5'e göre $-3,45$ düzeyinde çıkmıştır. $-3.4<-2.58$ olduğu için Ho hipotezi reddedilir. Birim kök testi yoktur seri durağandır denilebilmektedir.

Tablo 5. Johansen Eşbütünleşme Testi Sonuçları

\begin{tabular}{|l|l|l|l|l|}
\hline Değişkenler & $\begin{array}{l}\text { Karakteristik } \\
\text { Kökler }\end{array}$ & Test İstatistiği & Kritik Değer (\%5) & Prob \\
\hline İthalat-Enflasyon & 0.152628 & 24.92024 & 15.49471 & 0,0014 \\
\hline
\end{tabular}


Johansen eşbütünleşme testi sonuçları incelendiğinde, istatistiksel bir anlamlı ilişkinin olmadığı ifade edilebilir. Boş hipotez olan eş bütünleşmenin olmadığı yönündeki hipotez geçersizdir. Hipotez reddedilir. Test sonucunun anlamlı olması eş bütünleşme olduğunun göstergesidir.\%5 anlamlılık oranı üzerinden modelde yer alan değişkenler arasında anlamlılık ilişkisi mevcuttur sonucuna ulaşılmaktadır.

Tablo 6. Granger Nedensellik Testi Sonuçları

\begin{tabular}{|l|l|l|c|}
\hline & Gözlem & F-Statistic Değeri & Anlamlılık Düzeyi \\
\hline İhracat-İthalat & 103 & 0.68392 & 0.6368 \\
İthalat-İhracat & & 2.78139 & 0.0219 \\
\hline Enflasyon-İhracat & 103 & 1.01921 & 0.4110 \\
İhracat- Enflasyon & & 0.52598 & 0.7561 \\
\hline Enflasyon- İthalat & 103 & 1.94568 & 0.0943 \\
İthalat- Enflasyon & & 2.84594 & 0.0196 \\
\hline
\end{tabular}

Granger nedensellik analizi sonuçları incelendiğinde; Tablonun son sütununda kuyruk olasılıkları verilmektedir. Kuyruk olasılıklarının belirlenen alfa anlamlılık düzeyinde $(0,05)$ düşük olması H0 hipotezinin reddedilebileceğini gösterecektir. Tersi durumda ise H0 reddedilemez. İlk olarak İhracat ile İthalat ve İthalat ile İhracat sonucuna bakıldığında ihracat ithalatın nedeni değildir. İthalat ihracatın nedenidir denilebilmektedir. Sonuca bakıldığında tek taraflı bir nedensellik vardır. İthalattan ihracata doğru tek yönlü bir nedensellik ilişkisi vardır.

Enflasyon ile İhracat ve İhracat ile Enflasyon arasındaki nedensellik analizi sonucunda enflasyon ihracatın nedenidir denilebilir. Ayrıca İhracatta enflasyonun nedenidir denilebilmektedir. Sonuç olarak iki değişken arasında nedensellik vardır. Hem enflasyon ile ihracat nedenselliği, hem de ihracat ile enflasyonun nedenselliği söz konusu olduğu için iki yönlü bir nedensellik ilişkisi söz konusudur. Buradan yola çıkarak her iki değişkende birbirinin Granger nedeni olmaktadır. Ancak enflasyonun ihracatı etkilemesi, ihracatın enflasyonu etkilemesinden daha kuvvetli olmaktadır. Bunun nedeni F istatistiği değerinin daha yüksek, olasılık değerinin daha düşük olmasıdır.

Enflasyon ile İthalat ve İthalat ile Enflasyon arasındaki nedensellik analizi sonucunda enflasyon ithalatın nedeni değildir. İthalat ise enflasyonun nedenidir sonucuna ulaşılmıştır. Sonuca bakıldığında tek taraflı bir nedensellik vardır. Sonuçta ithalattan enflasyona doğru tek yönlü bir nedensellik ilişkisi olduğu görülmektedir.

Aşağıdaki grafikte bu ilişkilerin yönünün topluca gösterimi oklar vasıtası ile yapılmıştır.

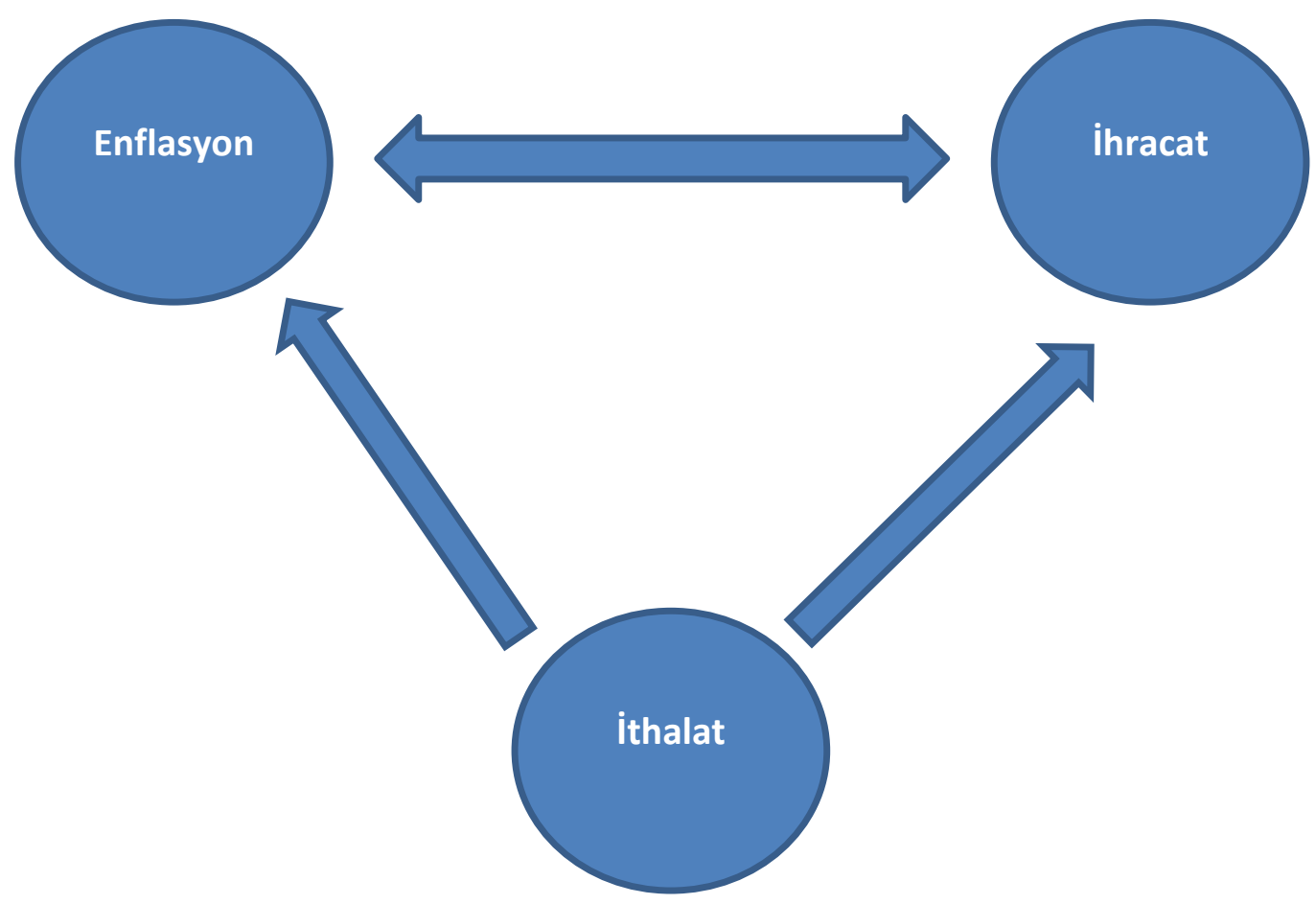


Genel olarak enflasyonla ihracat arsında iki yönlü, ithalat enflasyonla arasında tek yönlü ve ithalat ihracat arasında yine tek yönlü bir ilişki söz konusu olmaktadır.

\section{Sonuç}

Türkiye'de tarihsel süreç içerisinde bir takım ekonomik sorunlar her zaman söz konusu olmuştur. Bu sorunların en çok karşılaşılanı şüphesiz enflasyon olagelmektedir. Enflasyonla mücadele konusunda ekonomi politikası uygulayıcıların enflasyona sebep olan temel etkenleri bilmesi ve mücadeleyi yaparken bu sebeplerle birlikte yapması kaçınılmazdır. Özellikle 1980 sonrası dışa açık bir ekonomi modeli izleyen Türkiye ekonomisi dış ticaret alanında oldukça yol kat etmiştir. Hem ihracat hem de ithalat ekonomiyi doğrudan etkileyen kalemler haline gelmişlerdir. Özellikle belli kırılma dönemleri aralıklı olarak nedensellik ilişkisi yaparak enflasyon ilişkisini incelmek ekonomi politikası uygulayıcılarına yarar sağlayabilmektedir.

Çalışmada enflasyon ile dış ticaret verileri olan ithalat ve ihracat arsındaki ilişki incelenmiştir. Çalışmada kullanılan serilerin durağanlığı test edilmiştir. Seriler durağan hale geldikten sonra Johansen eşbütünleşme testi ve Granger nedensellik analizi uygulaması yapılmıştır. Çalışmada eşbütünleşme analizi sonucunda seriler arasında anlamlılık ilişkisi vardır. Granger nedensellik analizine göre ise önce; Tablonun son sütununda kuyruk olasılıkları verilmektedir. Kuyruk olasılıklarının belirlenerek alfa anlamlılık düzeyinde $(0,05)$ düşük olması H0 hipotezinin reddedilebileceğini gösterecektir. Tersi durumda ise H0 reddedilemez. İhracat-İthalat ve İthalat-İhracat sonucuna bakıldığında ihracat ithalatın nedeni değildir. İthalat ihracatın nedenidir. Sonuca bakıldığında tek taraflı bir nedensellik vardır. Enflasyon-İhracat ve İhracat-Enflasyon sonucunda enflasyon ihracatın nedenidir. İhracat enflasyonun nedenidir. Sonuç olarak iki değişken arasında nedensellik vardır. Enflasyon-İthalat ve İthalat-Enflasyon sonucunda enflasyon ithalatın nedeni değildir. İthalat enflasyonun nedenidir. Sonuca bakıldığında tek taraflı bir nedensellik vardır sonuçlarına ulaşılmıştır.

\section{Kaynakça}

Ak, M. F. (2019). Türk Tarımında Çok Kriterli Karar Verme Yöntemleri ile Verimlilik Değerlendirme Modeli. Avrupa Bilim ve Teknoloji Dergisi, (17), 500-508

Aktaş, C. (2009). Türkiye'nin İhracat, İthalat ve Ekonomik Büyüme Arasındaki Nedensellik Analizi, Kocaeli Üniversitesi Sosyal Bilimler Enstitüsü Dergisi, 18(2): 35-47

Alkan, F. (2004). Enflasyon ve İstikrar Programlarl. Yüksek Lisans Tezi, Gazi Üniversitesi Sosyal Bilimler Enstitüsü, Ankara.

Altınok, S. (2004). İktisada Giriş (3. Baskı). Konya: Atlas Kitabevi

Ateş, İ. (2005). Türkiye Dış Ticaretinde Gelişmeler ve Yoksullaştıran Büyüme: 1993-2003, Adnan Menderes Üniversitesi, SBE, İktisat ABD, Yayınlanmamış Doktora tezi, Aydın.

Atik, H. (2006). Tercihlerde Benzerlik Teorisi: Türkiye ve Bazı Komșu Ülkelerin Dı̣s Ticareti Üzerine Bir Analiz, Ankara Üniversitesi Siyasal Bilgiler Fakültesi Dergisi, Cilt:61, Say1:2, ss.33-45.

Baldemir, E. ve Gökalp, F. (1999). Türkiye’de Döviz Kuru Ve Dış Ticaret Hadleri İlişkisinin Ekonometrik Analizi, IV. Ulusal Ekonometri ve Istatistik Sempozyumu Bildirileri, 17-40.

Bayraktutan, Y. ve Arslan, İ. (2003). Türkiye'de Döviz Kuru, İthalat ve Enflasyon İlişkisi: Ekonometrik Analiz (1980-2000), Afyon Kocatepe Üniversitesi İ.I.B.F. Dergisi, 5(2), 89-104.

Bayraktutan, Y. (2003). Bilgi ve Uluslararası Ticaret Teorileri, Cumhuriyet Üniversitesi, IIBFF Dergisi, Cilt: 4, Sayı: 2, Sivas, ss. 175186.

Berber, M. ve Artan, S. (2004). Enflasyon ve Ekonomik Büyüme İlişkisi: Türkiye Örneği. Tartışma Metni. Türkiye Ekonomi Kurumu. Yayın No: 2004/21.

Çeştepe, H., Yıldırım, E. ve Bayar, M. (2013), Doğrudan Yabancı Yatırım, Ekonomik Büyüme Ve Dış Ticaret: Toda-Yamamoto Yaklaşımıla Türkiye'den Nedensellik Kanıtları, Akdeniz İI.̈.B.F. Dergisi, 27: 1-37

Dinçer, B., Z. (1994). Yapısal Enflasyon Olgusu Işı̆̆ında Antienflasyon Politikaların Değerlendirilmesi ve Türkiye Örneği. Yüksek Lisans Tezi, Dokuz Ege Üniversitesi Sosyal Bilimler Enstitüsü, İzmir

Durukan, A. (1988). Enflasyon Ithali. Yüksek Lisans Tezi, İstanbul Üniversitesi Sosyal Bilimler Enstitüsü, İstanbul

Erim, N. (2007). Ikktisadi Düşünce Tarihi (1. Baskı). Ankara: Palme Yayıncılık

Göçer, İ. ve Gerede, C. (2016). Dış Ticaretin Enflasyon Üzerindeki Etkileri: Türkiye İçin Zaman İçindeki Değişen Birim Kök ve Nedensellik Testleri. Eskişehir Osmangazi Üniversitesi, IIIBF Dergisi. A ̆gustos 2016.

Granger, C. W. J., (1969). Investigating Causal Relations by Econometric Models and Cross-Spectral Methods, Econometrica, Vol. 37 (3), 424-438.

Gül, E. ve Ekinci, A. (2006), Türkiye'de Reel Döviz Kuru ile İhracat ve İthalat Arasındaki Nedensellik İlişkisi: 1990-2006, Dumlupınar Üniversitesi Sosyal Bilimler Dergisi, Say1: 16, 165-190.

Hatemi-J, A. (2012), Asymmetric Causality Tests with an Application, Empirical Economics, 43(1), 447-456.

Hiç, M. (1994). Büyüme ve Gelişme Ekonomisi (2. Baskı). İstanbul: Filiz Kitabevi

İyibozkurt, M., E. (1995). Uluslararası İktisat Teori ve Politika, Ezgi Kitabevi Yayınları, Bursa.

Johansen, S. (1988). Statistical Analysis of Cointegration Vectors, Journal of Economic Dynamics and Control, pp. $231-254$.

Kara, M. (2012). E-Dış Ticarette Karşılaşılan Sorunlar Üzerine Bir Araştırma: Gıda Sektörü Örneği, Yüksek Lisans Tezi, Fatih Üniversitesi Sosyal Bilimler Enstitüsü İstanbul.

Karaçor, Z. (2007). Enflasyon Kültür ve Geleneği: Türkiye Ekonomisi Üzerine Bir Analiz. Konya. (Editör: Ahmet Ay). Türkiye Ekonomisi. Konya: Çizgi Kitabevi, 99-102.

Karluk, R., S., (1991). Uluslararası Ekonomi, Geliştirilmiş 3. Baskı, Bilim Teknik Yayınevi, İstanbul.

Kaya F. ve Turguttopbaş, N.(2012). Dış Ticaret İşlemleri, Eskişehir, T.C. Anadolu Üniversitesi Yayınları, 2012.s. 57-89-90 
Kaya, V. ve Yılmaz, Ö. (2006). Bölgesel Enflasyon Bölgesel Büyüme İlişkisi: Türkiye İçin Zaman Serisi Ve Panel Veri Analizleri. İktisat Ișletme ve Finans, 21(247), 62-78.

Kebapçı, H. (2011). Bölgesel Kalkınmada Dış Ticaretin Rolü: Burdur-Isparta-Antalya İlerinin Karşılaştırması, Süleyman Demirel Üniversitesi, SBE, İktisat ABD, Yayınlanmamış Yüksek Lisans Tezi, Isparta

Keynes, J. M. (1936), The General Theory of Employment, Interest and Money, Cambridge: Harcourt, Brace and Company.

Koch, Paul D;. Rosensweigh, Jeffrey. A. (1992). The Dollar and the US Terms of Trade, Journal of Macroeconomics, Vol.14, pp. 467-486.

Mihaljek, D. ve Klau M. (2001). A Note on the Pass-Through from Exchange Rate and Foreign Price Changes to Inflation in Selected Emerging Market Economies, Bank of International Settlements Papers, No: 8, 69-108.

Oktay, N. (2005). Dış Ticarete Giriş, Anadolu Üniversitesi Yayını No: 1624, Açıköğretim Fakültesi Yayını: 848, Eskişehir.

Ordu, C. F. (2013). Döviz Kuru Dış Ticaret Illişkisi: Türkiye Örneği (Master's thesis, Adnan Menderes Üniversitesi, Sosyal Bilimler Enstitüsü).

Özarslan, U. (1998). Türk Bankacılık Sektörünün Ölçek Ekonomisi Açısından İncelenmesi (1978-1996), Marmara Üniversitesi, Bankacılık ve Sigortacılık Enstitüsü, Yayınlanmamıș Doktora Tezi, İstanbul.

Özel, H., A. (2012). Ticari Serbestleşmenin Teorik Temelleri ve Yeni Ticari Serbestleşme Modelleri, Kırklareli Üniversitesi, IIIBF Dergisi, Cilt: 1, Say1: 1, Mart Kirklareli, ss. 4-26.

Parasız, İ. (1996). Monetarizm ve Ünlü Monetarist ve Keynesgil İktisatçılarla Söyleşiler (2. Bask1). Bursa: Ezgi Kitabevi.

Saraç, T. B. (2009). Enflasyon ve Ekonomik Büyüme İlişkisi: Türkiye Ekonomisi Üzerine Ekonometrik Bir Uygulama (1988-2007). Doktora Tezi, Selçuk Üniversitesi Sosyal Bilimler Enstitüsü, Konya.

Şentürk, C. (2007). Dış Ticaret-Büyüme İlişkisi Üzerine Bir Inceleme: Türkiye ve Gelişmekte Olan Ülkelerde İhracata Dayalı Büyüme Hipotezinin Testi, Süleyman Demirel Üniversitesi, SBE, İktisat ABD, Yayınlanmamış Yüksek Lisans Tezi, Isparta

Toda, H. Y. ve T. Yamamoto (1995), Statistical Inference in Vector Autoregressions with Possbly Integrated Process, Journal of Econometrics, 66, 225-250.

Türker, O. (2002). Yeni Dış Ticaret Teorileri: Teori ve Uygulama, Erciyes Üniversitesi, SBE, Yayınlanmamış Yüksek Lisans Tezi, Kayseri.

Ulke, V. ve Ergün U. (2011), Econometric Analysis of Import and Inflation Relationship in Turkey between 1995 and 2010 , Journal of Economic and Social Studies, 1(2), 69-86.

Ulusoy, A. (2006). Maliye Politikası (4. Bask1). Trabzon: Üçyol Kitabevi.

Yapraklı, S. (2007), İhracat ile Ekonomik Büyüme Arasındaki Nedensellik: Türkiye Üzerine Ekonometrik Bir Analiz, ODTÜ Gelişme Dergisi, 34: 97-112

Yılmaz, K., Akçay, C. ve Alper, C. (2002). Enflasyon ve Büyüme Dinamikleri Gelişmekte Olan Ülkeler Işı̆̆ında Türkiye Analizi. İstanbul: Türk Sanayicileri ve İşadamları Derneği.

Yörük, D. (2008). Teoride Ve Uygulamada Dış Ticaret Hadleri ve Kalkınma İlişkisi, Marmara Üniversitesi, SBE, İktisat ABD, Uluslararası İktisat BD, Yayınlanmamış Yüksek Lisans Tezi, İstanbul. 